\title{
POLA ALIRAN PANAS BERDASARKAN ANALISIS FLUIDA DAN MINERAL UBAHAN \\ DI DAERAH PANAS BUMI SORIK MARAPI, KABUPATEN MANDAILING NATAL, PROVINSI SUMATRA UTARA
}

\section{HEAT FLOW PATTERN BASED ON ANALYSIS OF GEOTHERMAL FLUID AND ALTERATION MINERAL IN SORIK MARAPI REGION, MANDAILING NATAL DISTRICT, NORTH SUMATRA PROVINCE}

\author{
Hisyam Azhar Azizi', Agus Didit Haryanto', Johanes Hutabarat', Dicky Muslim¹, \\ Dewi Gentana ${ }^{1}$, dan Ryan Hidayat ${ }^{2}$ \\ ${ }^{1}$ Fakultas Teknik Geologi, Universitas Padjadjaran \\ ${ }^{2}$ KS Orka Renewables Pte Ltd. \\ hisyam16001@mail.unpad.ac.id
}

\begin{abstract}
ABSTRAK
Daerah panas bumi Sorik Marapi di Kabupaten Mandailing Natal, Provinsi Sumatra Utara merupakan sistem panas bumi bertemperatur tinggi yang diduga dari karakteristik kimia air panas yang muncul di permukaan. Kehadiran mineral ubahan seperti epidot pada serbuk bor sumur eksplorasi memperkuat pendugaan temperatur reservoir yang mencapai $235^{\circ} \mathrm{C}$. Karakteristik air panas bersifat lebih asam di sekitar fumarol dan mineral ubahan yang didapatkan dari sumur bor mencerminkan zona upflow sedangkan kelompok mata air panas berupa air klorida ber $\mathrm{pH}$ netral di sebelah utara dengan elevasi yang lebih rendah mencerminkan zona outflow sistem panas bumi di sini. Hal ini merupakan ciri khas aliran fluida panas yang terjadi di daerah panas bumi sistem vulkanik dengan morfologi terjal (steep terrain volcanic system) seperti halnya daerah Sorik Marapi.
\end{abstract}

Kata kunci: Sorik Marapi, geokimia, panas bumi, zona alterasi, upflow, outflow

\section{ABSTRACT}

Sorik Marapi geothermal area in Mandailing Natal Regency, North Sumatra Province has a high-temperature geothermal system that is interpreted from the chemical characteristics of hot springs. The presence of alteration minerals such as epidot in exploration well cutting samples strengthens the estimated reservoir temperature reaches $235^{\circ} \mathrm{C}$. The presence of hot water are more acidic hot spring around fumaroles and the minerals obtained from the drill well reflect the upflow zone while the hot spring group of neutral chloride water in the north with lower elevation reflects the outflow zone of the geothermal system here. This is a characteristic of hot fluid flow that occurs in geothermal areas of volcanic systems with steep terrain as well as Sorik Marapi area.

Keywords: Sorik Marapi, geochemical, geothermal, alteration zones, upflow, outflow

\section{PENDAHULUAN}

Panas bumi sebagai energi terbarukan merupakan sumber energi yang ramah lingkungan dan sangat cocok dikembangkan di masa depan untuk memenuhi kebutuhan energi. Indonesia terletak di pertemuan tiga lempeng aktif yang memungkinkan panas bumi dari kedalaman bumi ditransfer ke permukaan melalui sistem rekahan. Posisi strategis Indonesia menjadikan negara ini sebagai negara paling kaya dengan energi panas bumi dan sistem hidrotermal yang tersebar di sepanjang busur vulkanik. Potensi sumber energi panas bumi lebih besar dibandingkan dengan akumulasi sumber energi dari batubara, minyak dan gas bumi, serta uranium (Zulkifli, 2017). 
Pulau Sumatra merupakan bagian dari rangkaian busur vulkanik yang membentang dari Pulau Sumatra di bagian barat hingga ke Pulau Banda di bagian timur, yang dikenal dengan nama Busur Vulkanik Sunda - Banda. Di daerah Sumatra Utara, busur vulkanik ini memiliki potensi panas bumi kedua terbesar di Indonesia setelah Jawa Barat, termasuk di dalamnya adalah daerah Sorik Marapi.

Daerah penelitian secara administratif berada di Kabupaten Mandailing Natal, Provinsi Sumatra Utara. Daerah penelitian merupakan lapangan panas bumi PT. Sorik Marapi Geothermal Power, serbuk bor yang dijadikan sampel pada penelitian ini berasal dari sumur X-06, X-08 dan XE-01.

Tujuan dari penelitian ini adalah untuk mengetahui keberadaan zona aliran panas berdasarkan karakteristik fluida dan mineral alterasi di daerah penelitian-

\section{GEOLOGI}

Pulau Sumatra merupakan pulau ke 6 (enam) terbesar di dunia. Secara ekspresi fisiografi, pulau ini memiliki orientasi berarah baratlaut-tenggara. Luas pulau ini $\pm 435.000 \mathrm{~km}^{2}$, dengan panjang $1.650 \mathrm{~km}$ dari Banda Aceh di bagian utara hingga Tanjungkarang di bagian selatan. Lebar berkisar antara 100-200 km di bagian utara dan sekitar $350 \mathrm{~km}$ di bagian selatan (Juliarka \& Iqbal, 2019). Pegunungan Barisan yang berada sepanjang bagian barat membagi pantai barat dan timur Pulau Sumatra. Lereng yang mengarah ke Samudera Hindia pada umumnya curam sehingga menyebabkan sabuk bagian barat biasanya berupa pegunungan. Sabuk bagian timur pada pulau ini ditutupi oleh formasi Tersier dan dataran rendah aluvial (Darman dan Sidi, 2000).

Pulau Sumatra merupakan bagian Sundaland yang terletak di bagian baratdaya. Oleh karena itu, teori tentang pembentukan Sumatra tidak terlepas dengan sejarah pembentukan Sundaland itu sendiri (Darman dan Sidi, 2000).
Secara regional geologi daerah penelitian berdasarkan pada Peta Geologi Lembar Lubuk Sikaping, Sumatra Utara skala 1:250.000 (Aldiss, 1983). Daerah penelitian berada di dalam terban (graben) Penyabungan yang merupakan bagian dari sesar Sumatra. Gunung Sorik Marapi berjarak sekitar $15 \mathrm{~km}$ ke arah baratlaut dari sesar Sumatra dan berdekatan dengan busur magmatik yang terbentuk di Pulau Sumatra yaitu Pegunungan Bukit Barisan.

Secara umum geologi daerah Sorik Marapi tersusun oleh batuan vulkanik Tersier dan batuan Kuarter. Batuan Tersier pada umumnya berkomposisi andesitik, sedangkan batuan Kuarter pada umumnya tersusun oleh batuan vulkanik yang berkomposisi dasitik dan batuan sedimen.

Daerah penelitian terdiri dari tujuh satuan batuan, yang terdiri dari dua satuan batuan gamping, dua satuan batuan vulkanik, satu satuan batuan terobosan, satu satuan batuan metamorf dan satu satuan endapan permukaan (aluvium). Sebagian dari batuan vulkanik tersebut diperkirakan berasal dari titik erupsi yang berbeda, yaitu Gunung Sirakara yang berumur Tersier, dan Gunung Sorik Marapi yang berumur Kuarter. Batuan gamping di daerah penelitian berumur Paleozoikum dan/atau Mesozoikum tak terbedakan (dipetakan secara tersendiri), sedangkan endapan permukaan terdiri dari material lepas yang termasuk dalam satuan aluvium. Stratigrafi satuan batuan secara berurutan dari tua ke muda adalah Satuan Metamorf (Puku), Satuan Batugamping (Mpu), Batuan terobosan (Mpip), Anggota Batugamping (Ppsl), Satuan Tuff (Tmv), Lahar Andesitik dan Breksi Gunungapi (Qvsm), dan Lava Andesit (Qhvsm) (Gambar 1).

\section{METODE}

\section{Analisis Geokimia Panas Bumi}

Analisis geokimia bertujuan untuk mengelompokkan fluida panas bumi berdasarkan perbandingan (rasio) unsur dan klasifikasinya, serta untuk memperoleh data kimia fluida dan gas, serta unsurunsur lain yang terkandung dalam 
manifestasi panas bumi sehingga dapat mengetahui jenis fluida, zona upflow dan zona outflow pada sistem panas bumi serta menentukan aliran air panasnya.

Dalam penelitian ini data kimia yang digunakan adalah data kimia air dari manifestasi panas bumi yang diolah dengan menggunakan geoindikator dari masing-masing rasio unsur kimia air, selain itu juga dilakukan analisis isotop stabil. Hal ini akan menginformasikan kondisi reservoir, aliran dan lingkungan pembentukan fluida, zona upflow dan outflow dari suatu sistem panas bumi di kedalaman (Nicholson, 1993).

\section{Geoindikator}

Giggenbach (1988) membagi zat-zat terlarut dalam dua katagori yaitu tracer dan geoindikator. Tracer secara geokimia bersifat inert (misalnya $\mathrm{Li}, \mathrm{Rb}, \mathrm{Cl}$ dan $\mathrm{B}$ ) yang apabila ditambahkan ke dalam fluida akan bersifat tetap dan dapat diidentifikasi asal usul fluidanya. Geoindikator adalah zat terlarut yang bersifat reaktif dan mencerminkan lingkungan equilibrium (kesetimbangan), misalnya $\mathrm{Na}$ dan $\mathrm{K}$. Beberapa tipe geoindikator kimia panas bumi menurut Giggenbach and Goguel (1989) yaitu:

- Geoindikator Cl-SO4-HCO3

- Geoindikator Cl-Li-B.

- Geoindikator Na-K-Mg.

\section{Geotermometer}

Geotermometer merupakan parameter untuk menghitung atau mengukur temperatur air yang ada dalam wilayah sumber air panas dengan menggunakan termometer, dan yang menjadi objek pengukurannya adalah kandungan unsur kimia yang ada di dalam air tersebut. Adapun cara yang lain digunakan adalah dengan menggunakan persamaan yang telah ditetapkan tergantung unsur-unsur yang terkandung di dalam air (Prihadi, 2006) yaitu:

- Geotermometer Silika.

- Geotermometer Na-K.

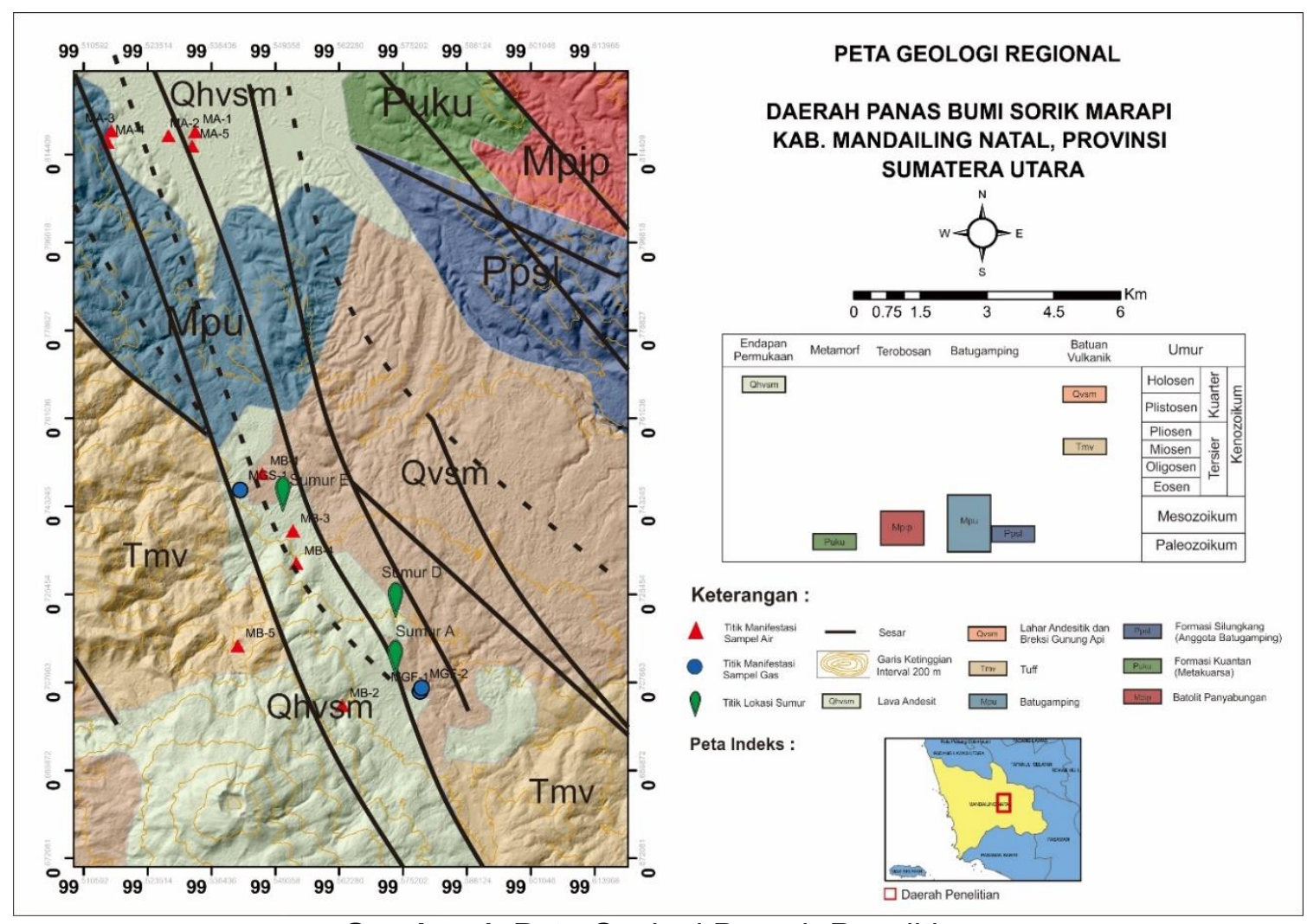

Gambar 1. Peta Geologi Daerah Penelitian

(diadaptasi dari Peta Geologi Lembar Lubuk Sikaping oleh D.T. Aldiss, 1983) 


\section{MAKALAH ILMIAH}

\section{Analisis Petrografi}

Melakukan deskripsi sayatan tipis batuan dan sampel serbuk (cutting) yang hasilnya berupa jenis litologi dan komposisi mineral, kehadiran mineral alterasi dan intensitas alterasi dengan bantuan mikroskop dan klorida $(\mathrm{HCl})$. Analisis petrografi batuan dilakukan untuk penamaan jenis batuan dengan pendekatan kuantitatif, yang di amati dari sayatan tipis juga sampel cutting dan kemudian mengestimasi persentase material penyusun batuan tersebut.

Deksripsi mineral primer dan sekunder dilakukan berdasarkan sifat optik dari mineral transparan dibawah mikroskop baik pada nikol sejajar (PPL) dan nikol bersilang (XPL). Deskripsi sifat optik dan genesa mineral mengacu pada buku Atlas of Alteration: A field and Petrographic Guide to Hydrothermal Alteration Minerals (1997) oleh Thompson serta Important

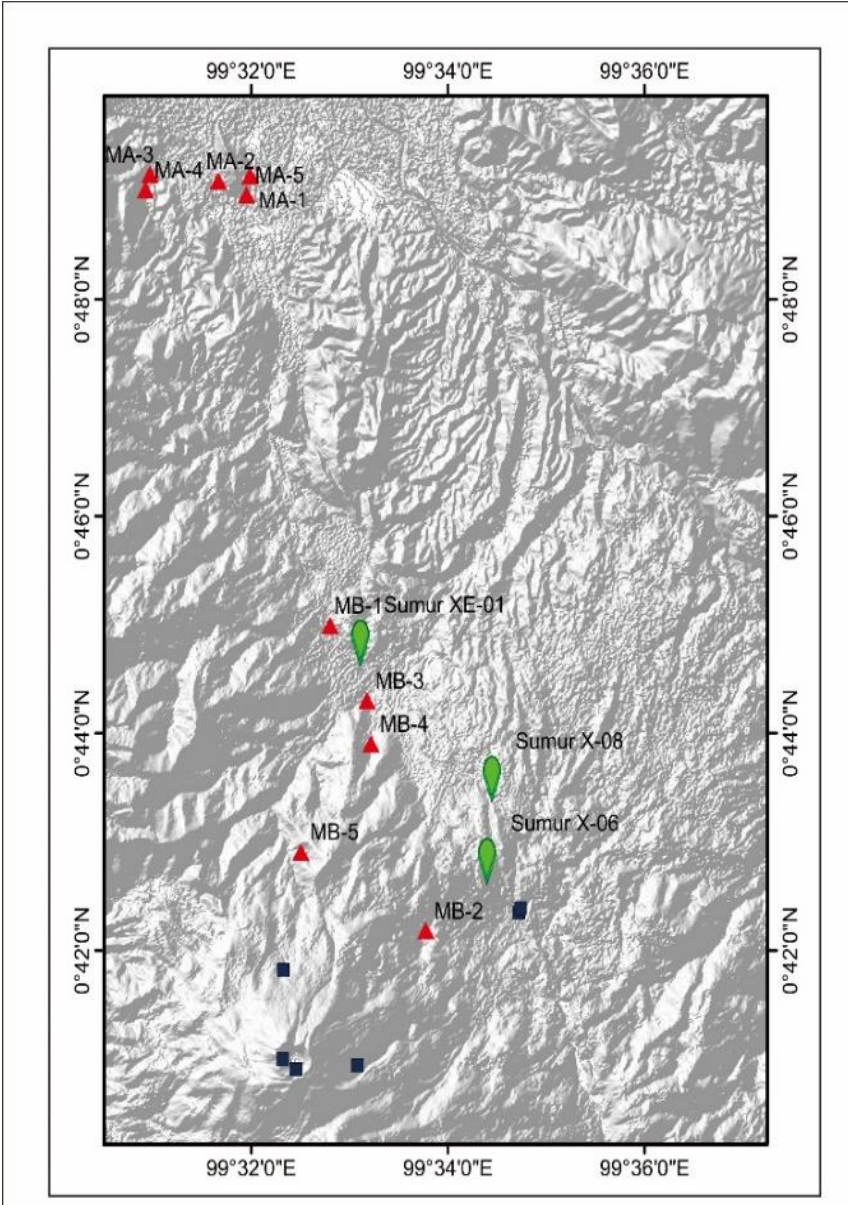

Hydrothermal Minerals and their Signifance oleh Kingston Morrison beserta referensi lainnya.

\section{HASIL DAN PEMBAHASAN}

\section{Penyebaran Manifestasi dan Titik Sumur di Daerah Penelitian}

Karakteristik fluida panas bumi dapat diketahui dari manifestasi yang muncul di permukaan. Manifestasi panas bumi yang ditemukan di daerah Sorik Marapi berupa manifestasi air panas di 10 (sepuluh) lokasi dan terdapat 3 (tiga) sumur yang menjadi objek penelitian (Gambar 2). Dari analisis geokimia yang dilakukan terhadap beberapa sampel air di daerah penelitian, memberikan gambaran mengenai tipe fluida, kondisi reservoir dan sumber fluidanya sedangkan dari analisis petrografi sumur penelitian dapat diketahui zona alterasinya.

\section{PETA SEBARAN MANIFESTASI DAN TITIK SUMUR PENELITIAN}

\section{DAERAH PANAS BUMI SORIK MARAPI KAB. MANDAILING NATAL, PROVINSI SUMATERA UTARA}

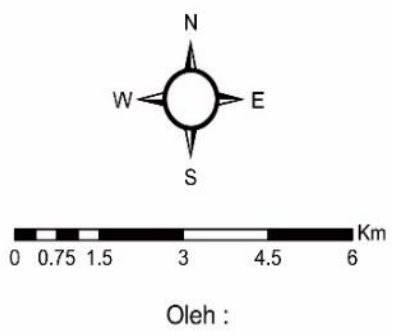

Hisyam Azhar Azizi

Keterangan :

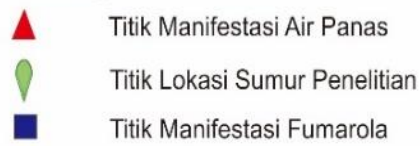

Peta Indeks :

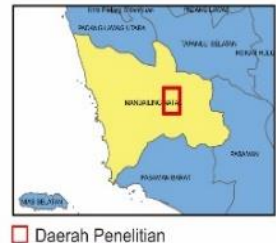

Gambar 2. Peta sebaran manifestasi panas bumi dan titik sumur permukaan yang menjadi objek penelitian. 


\section{Litologi Sumur Penelitian}

Pengamatan litologi dilakukan pada 3 (tiga) sumur yaitu X-06, X-08 dan XE-01 yang didominasi oleh produk vulkanik seperti lava andesit, dacite tuff dan rhyolite tuff serta produk metamorf seperti phyllite dengan tingkat alterasi dari lemah hingga sangat kuat. Litologi dari 3 (tiga) sumur tersebut terdiri dari tiga satuan stratigrafi dari tua ke muda berupa satuan Metagunung api berupa phyllite, Satuan Tuff berupa dacite tuff dan rhyolite tuff yang sudah teralterasi, dan satuan lava andesit.

Hasil pengamatan mikroskopis dan megaskopis, sumur X-06 memiliki litologi dacite tuff. Pada sumur ini terlihat intensitas alterasi dari sedang $(40 \%)$ hingga sangat kuat $(85 \%)$ menurut klasifikasi intensitas alterasi oleh Browne (1991). Intensitas alterasi meningkat seiring bertambahnya kedalaman. Mineral primer berupa plagioklas, kuarsa, piroksen dan k-felspar, dan mineral sekunder berupa kalsit, lempung, klorit, epidot, serisit, magnetit, pirit, kuarsa sekunder, hematit dan anhidrit. Mineral sekunder epidot, serisit, dan anhidrit muncul pada kedalaman $910 \mathrm{mKU}$, sedangkan mineral sekunder seperti hematit, lempung dan klorit berkurang seiring bertambahnya kedalaman.

Hasil pengamatan mikroskopis dan megaskopis, sumur X-08 memiliki litologi lava andesit, rhyolite tuff dan phyllite. Pada sumur ini terlihat intensitas alterasi dari rendah $(10 \%)$ hingga sangat kuat (85\%) menurut klasifikasi intensitas alterasi oleh Browne (1991). Intensitas alterasi meningkat seiring bertambahnya kedalaman. Mineral primer berupa plagioklas, kuarsa, piroksen dan k-felspar dan mineral sekunder berupa kalsit, lempung, klorit, epidot, magnetit, pirit, kuarsa sekunder dan hematit. Mineral sekunder epidot dan klorit muncul pada kedalaman $1.790 \mathrm{mKU}$, sedangkan mineral sekunder seperti hematit dan lempung berkurang seiring bertambahnya kedalaman.
Hasil pengamatan dan megaskopis, sumur XE-01 memiliki litologi filit. Pada sumur ini terlihat intensitas alterasi dari sedang $(40 \%)$ hingga sangat kuat $(90 \%)$ menurut klasifikasi intensitas alterasi oleh Browne (1991). Intensitas alterasi meningkat seiring bertambahnya kedalaman. Mineral primer berupa plagioklas, kuarsa, piroksen dan k-felspar, dan mineral sekunder berupa kalsit, lempung, klorit, epidot, magnetit, pirit, kuarsa sekunder dan hematit. Mineral sekunder kalsit, pirit, klorit, epidot, serisit dan anhidrit muncul pada kedalaman $1.533 \mathrm{mKU}$, sedangkan mineral sekunder seperti kalsit, klorit, serisit, anhidrit dan lempung berkurang seiring bertambahnya kedalaman.

\section{ZONA ALTERASI SUMUR PENELITIAN}

\section{Zona Alterasi Sumur X-06}

Berdasarkan kelimpahan asosiasi mineral ubahan, sumur ini terbagi menjadi 3 zona alterasi yaitu : Zona Hematit, Zona KalsitKlorit, dan Zona Kalsit-Kuarsa Sekunder. (Tabel 6)

\section{- Zona Hematit}

Zona ini didominasi oleh kehadiran mineral hematit ditemukan pula mineral kalsit, kuarsa sekunder, pirit dan klorit. Zona ini terdapat pada kedalaman 499 s.d. 502 $\mathrm{mKU}$. Geotermometer mineral oleh Reyes (2000) menunjukan bahwa zona ini memiliki temperatur $120^{\circ} \mathrm{C}$ s.d. $170^{\circ} \mathrm{C}$.

\section{- Zona Kalsit-Klorit}

Zona ini didominasi oleh kehadiran mineral kalsit, klorit, kuarsa sekunder dan pirit ditemukan pula mineral hematit, lempung, epidot, serisit, magnetit dan anhidrit. Zona ini terdapat pada kedalaman 910 s.d. 913 mKU. Geotermometer mineral oleh Reyes (2000) menunjukan bahwa zona ini memiliki temperatur $170^{\circ} \mathrm{C}$ s.d. $230^{\circ} \mathrm{C}$.

\section{- Zona Kalsit - Kuarsa Sekunder}

Zona ini didominasi oleh kehadiran mineral kalsit, kuarsa sekunder, epidot dan pirit ditemukan pula mineral lempung, klorit dan 
magnetit. Zona ini terdapat pada kedalaman $1.861 \mathrm{mKU}$. Geotermometer mineral oleh Reyes (2000) menunjukkan bahwa zona ini memiliki temperatur $230^{\circ} \mathrm{C}$ s.d. $280^{\circ} \mathrm{C}$.

\section{Zona Alterasi Sumur X-08}

Berdasarkan kelimpahan asosiasi mineral ubahan, sumur ini terbagi menjadi 3 zona alterasi yaitu : Zona Hematit, Zona HematitKalsit, dan Zona Kalsit-Epidot (Tabel 6).

\section{- Zona Hematit}

Zona ini didominasi oleh kehadiran mineral hematit ditemukan pula mineral kalsit. Zona ini terdapat pada kedalaman $253 \mathrm{mKU}$. Geotermometer mineral oleh Reyes (2000) menunjukan bahwa zona ini memiliki temperatur $50^{\circ} \mathrm{C}$ s.d. $150^{\circ} \mathrm{C}$.

\section{- Zona Hematit-Kalsit}

Zona ini didominasi oleh kehadiran mineral hematit dan kalsit ditemukan pula mineral lempung, pirit, magnetit dan kuarsa sekunder. Zona ini terdapat pada kedalaman 860 s.d. 1.230 mKU. Geotermometer mineral oleh Reyes (2000) menunjukan bahwa zona ini memiliki temperatur $150^{\circ} \mathrm{C}$ s.d. $230^{\circ} \mathrm{C}$.

\section{- Zona Kalsit - Epidot}

Zona ini didominasi oleh kehadiran mineral kalsit, kuarsa sekunder dan epidot ditemukan pula mineral pirit, klorit, hematit dan magnetit. Zona ini terdapat pada kedalaman $1.790 \mathrm{mKU}$. Geotermometer mineral oleh Reyes (2000) menunjukkan bahwa zona ini memiliki temperatur $230^{\circ} \mathrm{C}$ s.d. $280^{\circ} \mathrm{C}$.

\section{Zona Alterasi Sumur XE-01}

Berdasarkan kelimpahan asosiasi mineral ubahan, sumur ini terbagi menjadi 3 zona alterasi yaitu : Zona Hematit, Zona Kalsit Klorit, dan Zona Kuarsa Sekunder - Pirit. (Tabel 6)

\section{- Zona Hematit}

Zona ini didominasi oleh kehadiran mineral hematit ditemukan pula mineral kuarsa sekunder, lempung dan magnetit. Zona ini terdapat pada kedalaman 813 s.d. 816 mKU. Geotermometer mineral oleh Reyes (2000) menunjukan bahwa zona ini memiliki temperatur $120^{\circ} \mathrm{C}$ s.d. $170^{\circ} \mathrm{C}$.

\section{- Zona Kalsit - Klorit}

Zona ini didominasi oleh kehadiran mineral kalsit, klorit, kuarsa sekunder dan pirit ditemukan pula mineral hematit, lempung, epidot, serisit, magnetit dan anhidrit. Zona ini terdapat pada kedalaman 1.533 s.d. $1.536 \mathrm{mKU}$. Geotermometer mineral oleh Reyes (2000) menunjukan bahwa zona ini memiliki temperatur $170^{\circ} \mathrm{C}$ s.d. $230^{\circ} \mathrm{C}$.

\section{- Zona Kuarsa Sekunder - Pirit}

Zona ini didominasi oleh kehadiran mineral kuarsa sekunder dan pirit ditemukan pula mineral klorit, hematit, lempung, epidot, kalsit dan magnetit. Zona ini terdapat pada kedalaman 2.391 s.d. 2.394 mKU. Geotermometer mineral oleh Reyes (2000) menunjukan bahwa zona ini memiliki temperatur $230^{\circ} \mathrm{C}$ s.d. $280^{\circ} \mathrm{C}$.

\section{Analisis Geokimia}

Pengolahan data geokimia didapatkan dari data manifestasi (Tabel 1) dengan hasil uji sampel laboratorium air (Tabel 2) yang diaplikasikan atau di plot pada diagram segitiga: $\mathrm{Cl}-\mathrm{SO}_{4}-\mathrm{HCO}_{3}, \mathrm{Cl}-\mathrm{Li}-\mathrm{B}$, dan $\mathrm{Na}-$ K-Mg.

\section{- Hasil dan Analisis Geokimia Air}

\section{Geoindikator $\mathrm{Cl}-\mathrm{SO}_{4}-\mathrm{HCO}_{3}$}

Hasil ploting ion kimia (geoindikator) pada diagram rasio $\mathrm{Cl}-\mathrm{SO}_{4}-\mathrm{HCO}_{3}$ akan menggambarkan tipe fluida dan karaktersistik reservoirnya, melalui pengolahan data dengan menghitung persentase masing-masing unsur $\mathrm{Cl}, \mathrm{HCO}_{3}$ dan $\mathrm{SO}_{4}$. Dari hasil plot geoindikator, jenis air panas bumi daerah Sorik Marapi terdiri atas tiga jenis air (Gambar 3). Berikut adalah uraian dari setiap jenis air panas bumi di daerah Sorik Marapi: 
Tabel 1. Data Manifestasi

\begin{tabular}{|c|c|c|c|c|c|c|c|c|c|c|}
\hline $\begin{array}{c}\text { No. } \\
\text { sample }\end{array}$ & $x$ & $\mathrm{Y}$ & $\begin{array}{c}\text { Elevation } \\
\text { (masl) }\end{array}$ & $\begin{array}{l}\text { Temp } \\
\left({ }^{\circ} \mathrm{C}\right)\end{array}$ & $\mathrm{pH}$ & $\begin{array}{l}\text { Flow } \\
(\mathrm{L} / \mathrm{s})\end{array}$ & Type & $\begin{array}{c}\text { Water } \\
\text { Sampling }\end{array}$ & $\begin{array}{l}\text { Gas/Steam } \\
\text { Sampling }\end{array}$ & $\begin{array}{c}\text { Stable } \\
\text { Isotope } \\
\text { Sampling }\end{array}$ \\
\hline MA-1 & 559314 & 90485 & 224 & 94.5 & 7 & $\sim 5$ & Hot spring & $\mathrm{V}$ & - & $\mathrm{V}$ \\
\hline MA-2 & 558720 & 90394 & 231 & 98.9 & 7 & $\sim 10$ & Hot spring & $\mathrm{V}$ & - & $\mathrm{V}$ \\
\hline MA-3 & 557433 & 90505 & 237 & 42.2 & 6 & $\sim 5$ & Flowing artesian bore & $\mathrm{V}$ & - & $\mathrm{V}$ \\
\hline MA-4 & 557348 & 90240 & 252 & 42.6 & 6 & $\sim 5$ & \begin{tabular}{|l|} 
Warm spring \\
\end{tabular} & $\mathrm{V}$ & - & $\mathrm{V}$ \\
\hline MA-5 & 559247 & 90157 & 245 & 101 & 7 & $\sim 0.5$ & Hot spring & $\mathrm{V}$ & - & $\mathrm{V}$ \\
\hline MB-1 & 560826 & 82849 & 506 & 76.4 & 6.5 & $\sim 0.5$ & Hot spring & $\mathrm{V}$ & - & $\mathrm{V}$ \\
\hline MB-2 & 562629 & 77662 & 1018 & 58.8 & $5-6$ & $\sim 1$ & Warm spring & $\mathrm{V}$ & - & $\mathrm{V}$ \\
\hline MB-3 & 561518 & 81566 & 564 & 51.3 & 7 & $<1$ & Warm spring & $\mathrm{V}$ & - & $\mathrm{V}$ \\
\hline MB-4 & 561599 & 80839 & 627 & 22.9 & 6 & 50 & Cold stream & $\mathrm{V}$ & - & $\mathrm{V}$ \\
\hline MB-5 & 560277 & 78995 & 1087 & 19.9 & 5 & $\sim 20$ & Cold stream & $\mathrm{V}$ & - & $\mathrm{V}$ \\
\hline- & 564388 & 78011 & 863 & 97.1 & - & - & Fumaroles & - & $\mathrm{V}$ & $\mathrm{V}$ \\
\hline- & 564423 & 78092 & 859 & 97.4 & - & - & Fumaroles & - & $\mathrm{V}$ & $\mathrm{V}$ \\
\hline- & 559942 & 77041 & 1489 & 94.4 & - & - & Fumaroles & - & $\mathrm{V}$ & $\mathrm{V}$ \\
\hline- & 560183 & 75356 & 2001 & 98.2 & - & - & Fumaroles & - & $\mathrm{V}$ & $\mathrm{V}$ \\
\hline- & 559941 & 75526 & 2025 & 91.5 & - & - & Fumaroles & - & - & $\mathrm{V}$ \\
\hline- & 561356 & 75423 & 1601 & 93.7 & - & - & Fumaroles & - & $\mathrm{V}$ & $\mathrm{V}$ \\
\hline
\end{tabular}

Tabel 2. Hasil analisis sample air.

\begin{tabular}{|l|c|c|c|c|c|c|c|c|c|c|c|}
\hline Sampel & $\begin{array}{c}\mathrm{HCO} \\
(\mathrm{mg} / \mathrm{l})\end{array}$ & $\begin{array}{c}\mathrm{B} \\
(\mathrm{mg} / \mathrm{l})\end{array}$ & $\begin{array}{c}\mathrm{Cal} \\
(\mathrm{mg} / \mathrm{l})\end{array}$ & $\begin{array}{c}\mathrm{Cl} \\
(\mathrm{mg} / \mathrm{l})\end{array}$ & $\begin{array}{c}\mathrm{Fe} \\
(\mathrm{mg} / \mathrm{l})\end{array}$ & $\begin{array}{c}\mathrm{Li} \\
(\mathrm{mg} / \mathrm{l})\end{array}$ & $\begin{array}{c}\mathrm{Mg} \\
(\mathrm{mg} / \mathrm{l})\end{array}$ & $\begin{array}{c}\mathrm{K} \\
(\mathrm{mg} / \mathrm{l})\end{array}$ & $\begin{array}{c}\mathrm{SiO} 2 \\
(\mathrm{mg} / \mathrm{l})\end{array}$ & $\begin{array}{c}\mathrm{Na} \\
(\mathrm{mg} / \mathrm{l})\end{array}$ & $\begin{array}{c}\mathrm{SO} 4 \\
(\mathrm{mg} / \mathrm{l})\end{array}$ \\
\hline MA-1 & 190 & 27 & 54 & 573 & 0.11 & 2.6 & 0.59 & 45 & 201 & 436 & 92 \\
\hline MA-2 & 207 & 26 & 59 & 559 & 0.33 & 2.6 & 0.86 & 44 & 177 & 421 & 88 \\
\hline MA-3 & 154 & 0.3 & 12.4 & 0.86 & 0.08 & 0.03 & 1.9 & 5 & 80 & 43 & 10.8 \\
\hline MA-4 & 150 & 0.3 & 18.2 & 0.78 & 0.08 & 0.02 & 3.4 & 4 & 72 & 34 & 10.9 \\
\hline MA-5 & 143 & 27 & 36 & 621 & 0.08 & 2.9 & 1 & 45 & 194 & 436 & 95 \\
\hline MB-1 & 200 & 0.3 & 37 & 1.4 & 0.28 & 0.01 & 9.3 & 10 & 109 & 37 & 30 \\
\hline MB-2 & 172 & 2.9 & 218 & 326 & 0.08 & 0.12 & 70 & 37 & 224 & 117 & 349 \\
\hline MB-3 & 124 & 0.3 & 18.3 & 4.2 & 0.08 & 0.01 & 4.1 & 11 & 112 & 25 & 14.3 \\
\hline MB-4 & 89 & 0.3 & 16.3 & 1 & 0.08 & 0.01 & 6.4 & 3.1 & 83 & 8.3 & 3.7 \\
\hline MB-5 & 41 & 0.3 & 9.2 & 0.72 & 0.08 & 0.01 & 2.9 & 2.3 & 49 & 4.7 & 4.7 \\
\hline
\end{tabular}

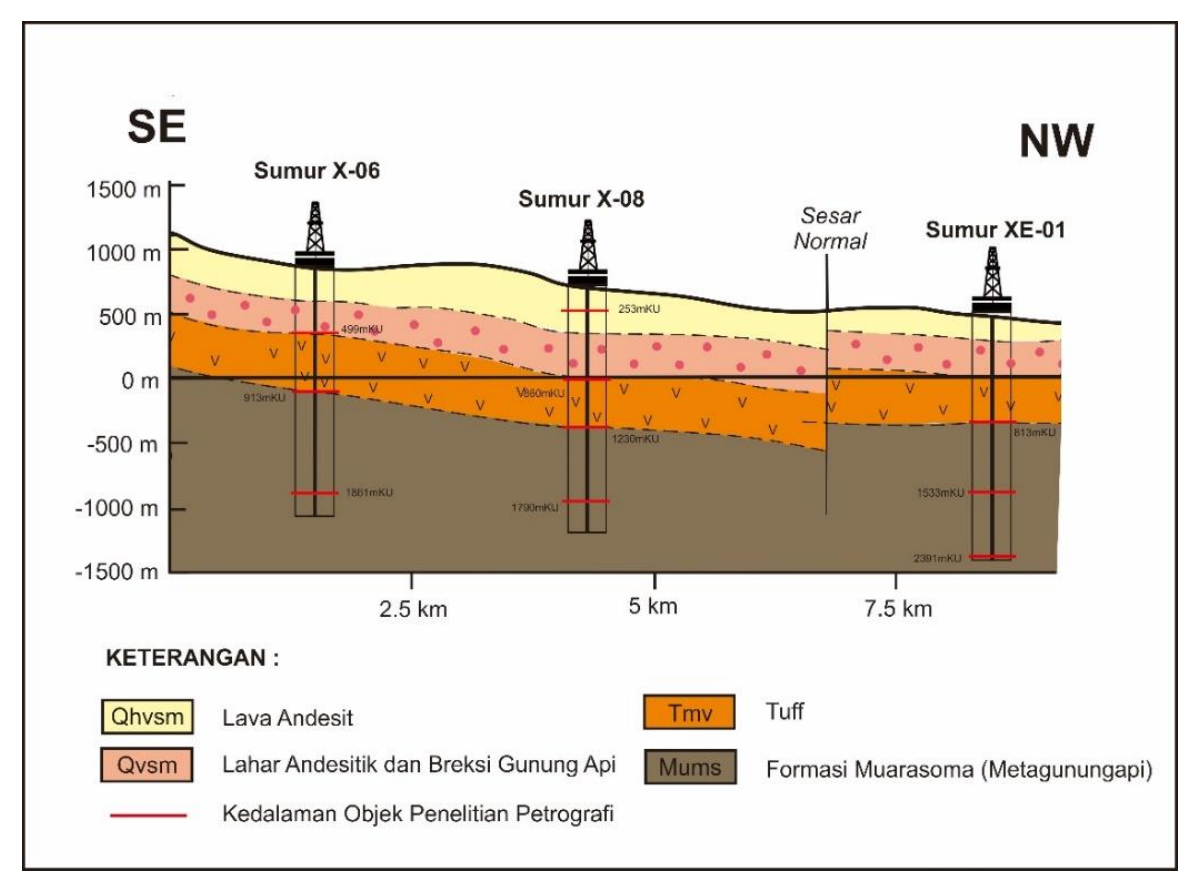

Gambar 3. Litologi sumur penelitian 


\section{Air Klorida}

Jenis air klorida memiliki komposisi $\mathrm{Cl}$ yang dominan dibandingkan dengan komposisi $\mathrm{SO}_{4}$ dan $\mathrm{HCO}_{3}$, terbentuk pada kondisi mature water, terdapat pada manifestasi mata air panas MA-1, MA-2 dan MA-5. Kehadiran klorida yang mendominasi, menunjukkan bahwa mata air panas tersebut berasal dari air panas bumi yang muncul ke permukaan pada zona lemah, bergerak jauh secara lateral sebagai outflow. Pada sistem panas bumi dataran tinggi jenis air klorida dapat mengidentifikasi daerah permeabel zona tinggi, fluida keluar melewati jalur sesar atau pada daerah yang mengalami tektonik aktif, pengangkatan (uplift) sedang hingga tinggi dan terdeformasi. Hal tersebut diperoleh melalui perhitungan indeks geomorfik kuantitatif antara lain; stream length gradient index (SI), valley height width ratio (Vf) dan basin shape index (Bs), sebagai parameter morfotektonik (Gentana, D., 2018).

\section{Air Sulfat - Klorida}

Jenis air sulfat-klorida memiliki komposisi $\mathrm{SO}_{4}$ dan $\mathrm{Cl}$ yang sama-sama dominan dibandingkan dengan komposisi $\mathrm{HCO}_{3}$ yang minim, terdapat pada manifestasi mata air panas MB-2. Air panas MB-2 ini diinterpretasikan terbentuk dari fluida panas bumi yang saat bergerak ke permukaan mengalami percampuran (mixing) dengan air klorida yang juga bercampur dengan batuan yang dilewatinya mengandung sulfur dan ion sulfat $\left(\mathrm{H}_{2} \mathrm{~S}\right)$ diperlihatkan oleh komposisi $\mathrm{SO}_{4}$ yang signifikan. Air panas MB-2 muncul ke permukaan sebagai upflow, pada kondisi steam heated water dan volcanic water. Hal tersebut menunjukkan telah terbentuk sistem kesetimbangan fluida panas bumi di kedalaman yang dipengaruhi oleh adanya proses percampuran (mixing) dan pelarutan (diluted) serta interaksi antara fluida dengan batuan yang dilaluinya (water rock interaction) selama perjalanan fluida dari reservoir menuju ke permukaan.

\section{Air Bikarbonat}

Jenis air bikarbonat memiliki senyawa $\mathrm{HCO}_{3}$ yang dominan terdapat pada manifestasi mata air panas MA-3, MA-4, MB- 1, MB-3, MB-4, dan MB-5. Kehadiran unsur $\mathrm{HCO}_{3}$ dominan yang dapat berasal dari kondensasi gas $\mathrm{CO}_{2}$ dengan air tanah atau air permukaan (meteoric water) dan jenis air ini termasuk ke dalam daerah peripheral water yang muncul ke permukaan sebagai outflow.

\section{Geoindikator $\mathrm{Cl}-\mathrm{Li}-\mathrm{B}$}

Geoindikator Cl-Li-B diaplikasikan pada penelitian untuk mengetahui kesamaan asal air panas bumi dan memperkirakan batuan pada reservoir oleh adanya proses pengenceran berdasarkan perbandingan presentase konsentrasi Cl/100, Li dan B/4.

Hasil ploting berdasarkan data air di atas, pada diagram segitiga $\mathrm{Cl} / 100$, Li dan $-\mathrm{B} / 4$ (Gambar 4), memperlihatkan sampel air panas MA-3, MA-4, MB-1, MB-3, MB-4, dan MB- 5 berada pada posisi mendekati ke unsur Boron (B), hal ini menandakan bahwa selama perjalanannya air panas tersebut dari sumber panas ke permukaan mengalami banyak pengenceran oleh batuan yang dilewatinya. Proses pencucian (Leaching Rock) oleh batuan samping berupa batuan beku yang bersifat basalt menyebabkan tingginya kandungan unsur $B$, namun dikarenakan terdapat batuan sedimen di daerah penelitian, tidak menutup kemungkinan batuan sedimen mengalami proses pencucian dari fkuida ini. Fluida berada pada kondisi absorption of high $\mathrm{B} / \mathrm{Cl}$ steam.

Hasil ploting mata air panas MA-1, MA-2 dan MA-5 berada pada posisi dengan konsentrasi $\mathrm{Cl}$ dan $\mathrm{B}$ relatif seimbang dan masih menunjukan bahwa sedikit lebih ke posisi $B$, dapat diinterpretasikan ketiga mata air panas tersebut masih dipengaruhi oleh reaksi dengan batuan samping (basalt atau sedimen) pada kondisi $\mathrm{Li}$ less or $\mathrm{Cl}$ absorption dan mengalami proses penyerapan gas magmatik dengan rasio 
$\mathrm{B} / \mathrm{Cl}$ relatif seimbang dibandingkan dengan mata air panas lainnya. Mata air panas MB2 adalah satu-satunya manifestasi air panas pada posisi mendekat ke arah puncak $\mathrm{Cl}$ dibandingkan dengan seluruh mata air panas lainnya. Terdapatnya nilai konsentrasi $\mathrm{Cl}$ yang lebih besar pada mata air panas MB-2 ini dimungkinkan bahwa mata air panas yang naik ke permukaan adalah fluida yang berasal dari sumber panas dan mengalami pendinginan yang relatif cepat oleh batuan sekitar yang dilewatinya, namun dikarenakan unsur $\mathrm{Cl}$ mempunyai sifat yang susah bereaksi, mudah berpindah dan bersifat stabil, sehingga masih mendominasi pada saat air panas sampai di permukaan sebagai outflow pada kondisi absorption of low $\mathrm{B} / \mathrm{Cl}$ steam

Tabel 3. Rasio unsur $\mathrm{Cl} / \mathrm{B}$ untuk identifikasi reservoir panas bumi

\begin{tabular}{|c|c|c|c|c|}
\hline Sample & $\begin{array}{c}\mathbf{C l} \\
(\mathbf{m g} / \mathbf{l})\end{array}$ & $\begin{array}{c}\mathbf{B} \\
(\mathbf{m g} / \mathbf{l})\end{array}$ & $\mathbf{C l} / \mathbf{B}$ & Reservoir \\
\hline MA-1 & 573 & 27 & 21.2 & B \\
\hline MA-2 & 559 & 26 & 21.5 & B \\
\hline MA-3 & 0.86 & 0.3 & 2.9 & B \\
\hline MA-4 & 0.78 & 0.3 & 2.6 & B \\
\hline MA-5 & 621 & 27 & 23.0 & B \\
\hline MB-1 & 1.4 & 0.3 & 4.7 & B \\
\hline MB-2 & 326 & 2.9 & 112.4 & A? \\
\hline MB-3 & 4.2 & 0.3 & 14.0 & B \\
\hline MB-4 & 1 & 0.3 & 3.3 & B \\
\hline MB-5 & 0.72 & 0.3 & 2.4 & B \\
\hline
\end{tabular}

Hasil dari Cross Plot Rasio Cl/B dan Tabel rasio Cl/B (Gambar 5 dan Tabel 3) dengan ion klorida $(\mathrm{Cl})$ dan boron $(\mathrm{B})$ yang merupakan salah satu ion yang bersifat mobile dan dapat digunakan sebagai tracer atau jejak untuk menentukan origin fluida panas bumi (Giggenbach, 1991), mata air panas MA-1, MA-2, MA-5 dan MB-3 (rasio $\mathrm{Cl} / \mathrm{B}: 14-23 \mathrm{mg} / \mathrm{l}$ ) berada pada garis trend yang sama dengan kelompok mata air panas MA-3, MA-4 MB-1, MB-4, dan MB-5 (rasio $\mathrm{Cl} / \mathrm{B}: 2.4-4.6 \mathrm{mg} / \mathrm{l}$ ).

Meskipun ada perbedaan rasio dari dua kumpulan tersebut, hal ini dapat diinterpretasikan bahwa seluruh mata air panas di daerah penelitian merupakan bagian dari sistem panas bumi yang sama, namun memiliki perbedaan "usia". Sistem panas bumi yang dianggap "lebih tua" umumnya memiliki rasio $\mathrm{Cl} / \mathrm{B}$ yang lebih rendah (Giggenbach, 1991). Sedangkan pada mata air panas MB-2 tidak menunjukan trend yang sama dan memiliki rasio $\mathrm{Cl} / \mathrm{B}$ yang sangat tinggi sehingga diinterpretasikan merupakan sistem panas bumi tersendiri, maka diindikasikan terdapat 2 (dua) sistem panas bumi di daerah penelitian.

\section{Geoindikator $\mathrm{Na}-\mathrm{K}-\mathrm{Mg}$}

Dari data hasil analisis kimia air dilakukan perhitungan nilai $\mathrm{Na} / 1000, \mathrm{~K} / 100$, dan $\sqrt{ } \mathrm{Mg}$ menghasilkan persentase (kesetimbangan fluida) dari ketiga unsur tersebut yang di plot pada diagram segitiga Na-K-Mg.

Hasil ploting ion kimia $\mathrm{Na}-\mathrm{K}-\mathrm{Mg}$, dari 10 (sepuluh) sampel mata air panas di daerah penelitian (Gambar 6), memperlihatkan dari 7 (tujuh) lokasi mata air panas (MA-3, MA-4, MB-1, MB-2, MB-3, MB-4, dan MB5) memiliki nilai $\mathrm{Mg}$ relatif jauh lebih tinggi dan berada pada puncak nilai Mg bila dibandingkan dengan kandungan $\mathrm{K}$ dan $\mathrm{Na}$ dan kondisi fluida "Immature Waters", hal tersebut dapat diinterpretasikan bahwa fluida di titik lokasi tersebut telah mengalami proses percampuran dengan air permukaan (air tanah). Hasil ploting dari 3 (tiga) lokasi lainnya (MA-1, MA-2 dan MA5) memperlihatkan adanya peningkatan kandungan $\mathrm{Na}$ dan $\mathrm{K}$ pada kondisi fluida mencapai kesetimbangan, masuk ke dalam "Partial Equilibrium" pada temperatur reservoir : $\pm 237^{\circ} \mathrm{C}(\mathrm{MA}-1), \pm 239^{\circ} \mathrm{C}$ (MA-2) dan $\pm 238^{\circ} \mathrm{C}$ (MA-5).

Tabel 4 menunjukkan, bahwa air panas di daerah penelitian mempunyai nilai kandungan isotop deutrium berkisar $-55,9$ s.d. $-63,4(\%$ oo $)$ dan nilai oksigen 18 antara $-7,86$ s.d. $-9,39(\%)$. Nilai rasio dari conto air tersebut diplot pada grafik isotop stabil deutrium dan Oksigen 18 (Craig, 1961 dalam Nicholson, 1993) seperti pada Gambar 7 yang memperlihatkan adanya pengkayaan ${ }^{18} \mathrm{O}$ lebih jelas pada kelompok air panas MA-1, MA-2, dan MA-5, yang mengindikasikan telah terjadinya proses water-rock interaction pada pembentukan air panas tersebut. Sedangkan air panas 


\section{MAKALAH ILMIAH}

MB-2 (paling representatif dari kelompok air panas $\mathrm{MB}$ ) yang muncul pada bagian selatan daerah penyelidikan, pada elevasi lebih tinggi, bertemperatur di permukaan rendah $\left(58,8^{\circ} \mathrm{C}\right), \mathrm{pH}$ cenderung asam $(5-6)$, bertipe air sulfat dengan konsentrasi klorida cukup signifikan, tidak ada pengkayaan isotop ${ }^{18} \mathrm{O}$ (air panas terletak menempel pada garis MWL), sehingga diinterpretasikan bahwa ada indikasi pembentukan air panas MB-2 yang berasosiasi dengan proses leaching country-rock, dan merupakan zona upflow.

\section{Geotermometer}

Perhitungan geotermometer dilakukan dari sampel-sampel air yang telah diambil.
Berdasarkan perhitungan geotermometer metode Silika dan $\mathrm{Na} / \mathrm{K}$ yang diajukan oleh Fournier (1979) dan Giggenbach (1998), temperatur reservoir di manifestasi bagian utara (kelompok MA) ialah sekitar $118^{\circ}$ $246^{\circ} \mathrm{C}$ dan bagian selatan (kelompok MB) sekitar $101^{\circ}-405^{\circ} \mathrm{C}$ (Tabel 5).

Namun dikarenakan hanya fluida manifestasi yang berasal dari MA-1, MA-2, MA-5 dan MB-2 yang memiliki rasio HCO3$\mathrm{Cl}-\mathrm{SO} 4$, maka hasil perhitungan geotermometer dari 4 mata air panas tersebut lebih dapat dipercaya. Hasil perhitungan metode $\mathrm{Na}-\mathrm{K}-\mathrm{Mg}$ menurut Giggenbach (1998) juga menunjukkan temperatur yang hampir sama (Gambar 8).

Tabel 4. Data Isotop $\mathrm{d}^{18} \mathrm{O}$ dan $\mathrm{dD}$ di daerah penelitian

\begin{tabular}{ccccc}
\hline Sampel & ${\operatorname{Temp~}\left({ }^{\circ} \mathrm{C}\right)} \mathbf{C l}(\mathbf{p p m})$ & $\mathbf{d}^{18} \mathbf{O}(\mathbf{O} / \mathbf{o o})$ & $\mathbf{d D}(\mathbf{O} / \mathbf{o o})$ \\
\hline MA-1 & 95 & 573 & -7.86 & -55.9 \\
\hline MA-2 & 96 & 559 & -8.27 & -59 \\
\hline MA-3 & 42 & 0.9 & -8.76 & -58 \\
\hline MA-4 & 43 & 0.8 & -8.72 & -56.1 \\
\hline MA-5 & 101 & 621 & -7.92 & -57.4 \\
\hline MB-1 & 76 & 1.4 & -8.5 & -57.1 \\
\hline MB-2 & 59 & 326 & -9.14 & -63 \\
\hline MB-3 & 51 & 4.2 & -9.39 & -63.4 \\
\hline MB-4 & 23 & 1 & -8.87 & -56.6 \\
\hline MB-5 & 20 & 0.7 & -8.9 & -58.2 \\
\hline
\end{tabular}

Tabel 5. Data Hasil Perhitungan Geotermometer

\begin{tabular}{|c|c|c|c|c|c|c|c|c|c|c|c|}
\hline \multicolumn{2}{|c|}{ Sampel } & MA-1 & MA-2 & MA-3 & $\mathrm{MA}-4$ & MA-5 & MB-1 & MB-2 & $\mathrm{MB}-3$ & $\mathrm{MB}-4$ & MB-5 \\
\hline \multirow{2}{*}{$\begin{array}{c}\text { Metode } \\
\text { Silika } \\
\left(\mathrm{T}^{\circ} \mathrm{C}\right)\end{array}$} & $\begin{array}{c}\text { Quartz No Steam } \\
\text { Loss }\end{array}$ & 180 & 172 & 125 & 120 & 178 & 142 & 188 & 144 & 127 & 101 \\
\hline & $\begin{array}{l}\text { Quartz Max } \\
\text { Steam Loss }\end{array}$ & 168 & 161 & 122 & 118 & 166 & 137 & 175 & 138 & 124 & 102 \\
\hline \multicolumn{2}{|r|}{ Sampel } & MA-1 & MA-2 & $\mathrm{MA}-3$ & $\mathrm{MA}-4$ & $M A-5$ & MB-1 & MB-2 & $\mathrm{MB}-3$ & MB-4 & MB-5 \\
\hline \multirow{2}{*}{$\begin{array}{c}\text { Metode } \\
\mathrm{Na} / \mathrm{K} \\
\left(\mathrm{T}^{\circ} \mathrm{C}\right)\end{array}$} & (Fournier,1979) & 220 & 221 & 230 & 231 & 220 & 320 & 341 & 388 & 364 & 405 \\
\hline & $\begin{array}{c}\text { (Giggenbach,198 } \\
\text { 8) }\end{array}$ & 235 & 236 & 245 & 246 & 235 & 326 & 345 & 387 & 365 & 401 \\
\hline
\end{tabular}




\section{MAKALAH ILMIAH}

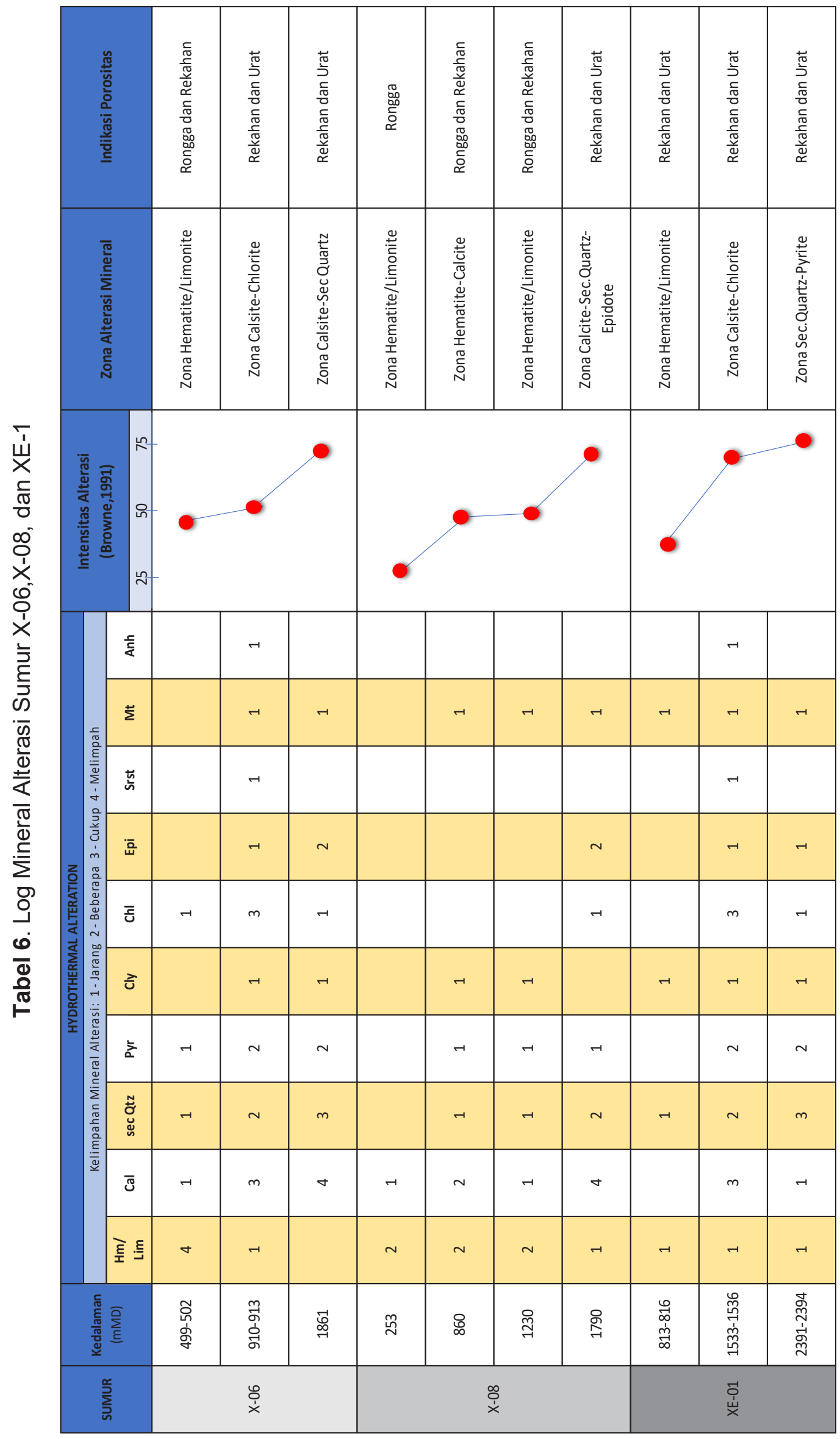




\section{MAKALAH ILMIAH}
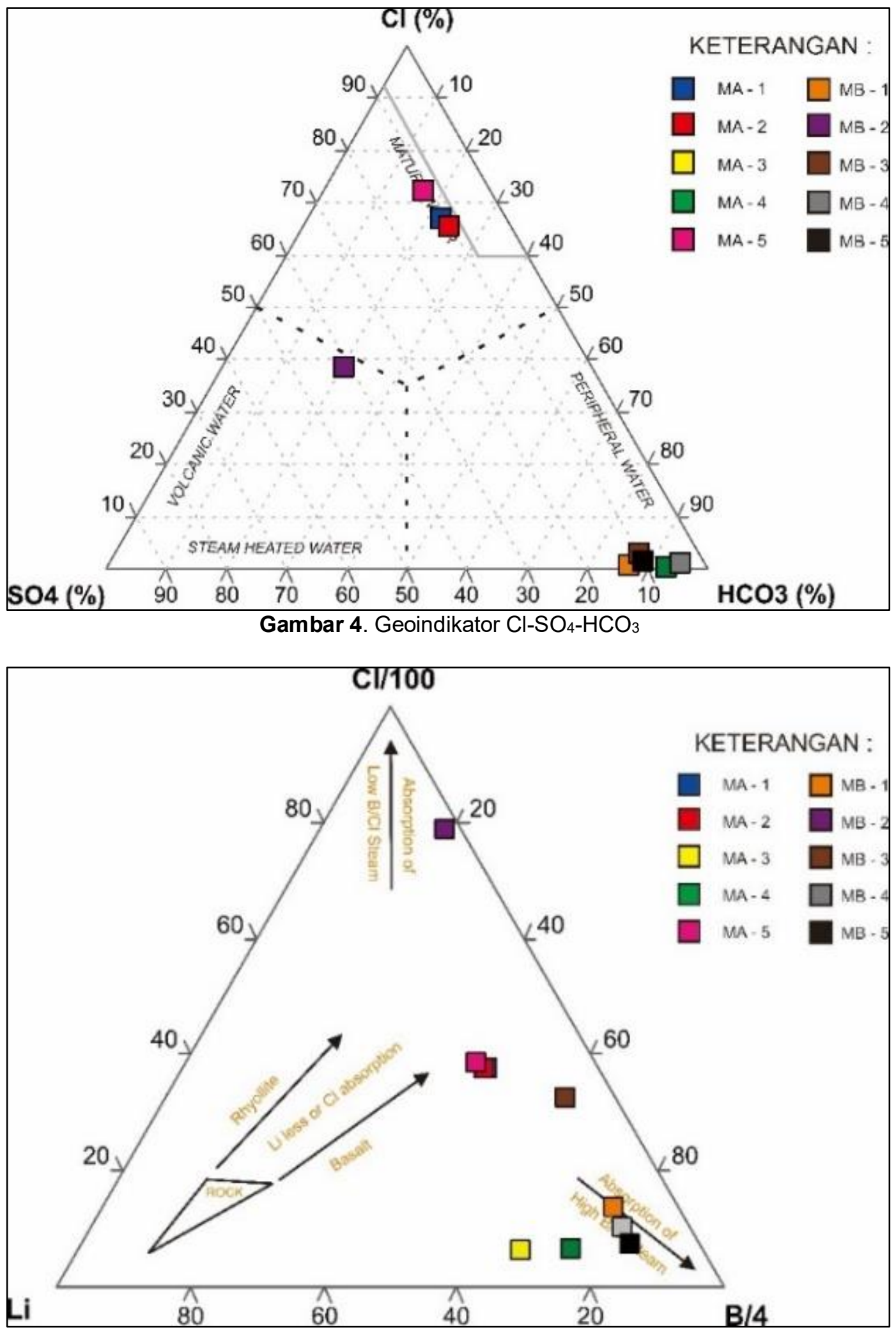

Gambar 5. Geoindikator Cl-Li-B 


\section{MAKALAH ILMIAH}

\section{Cross Plot Rasio Cl/B}

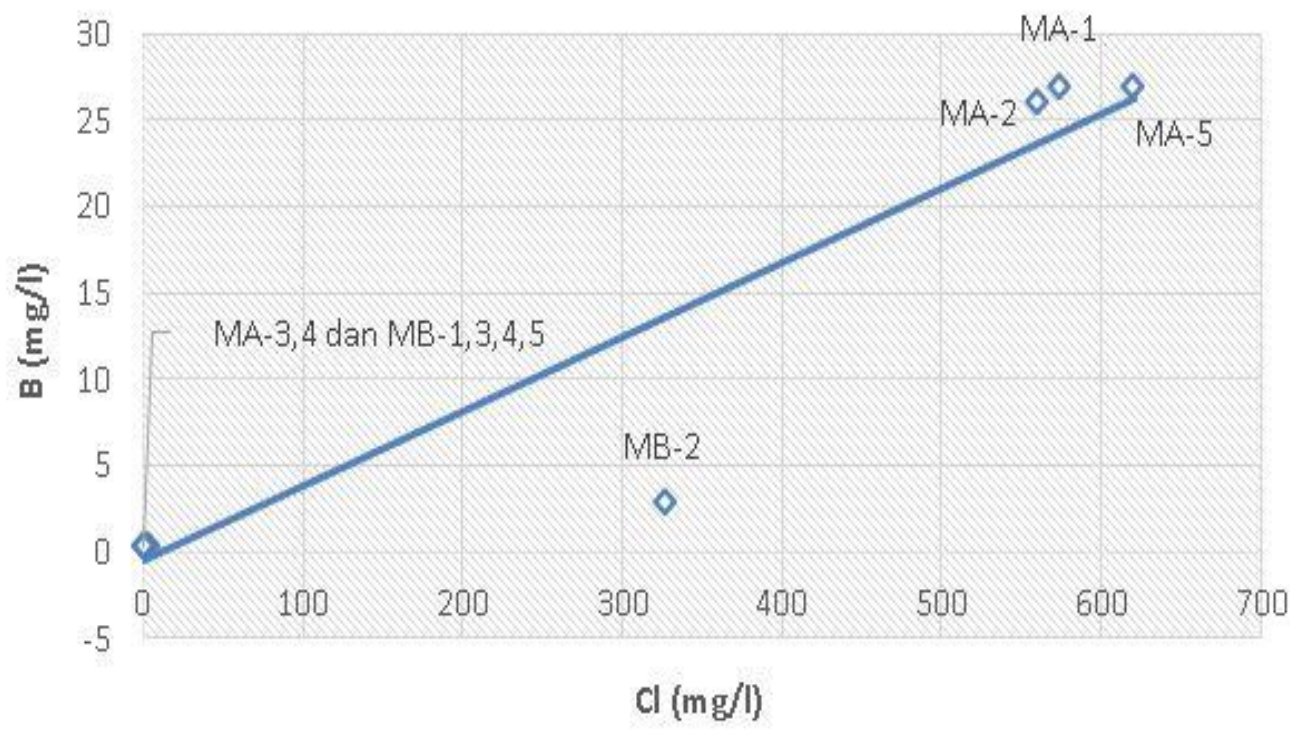

Gambar 6.Cross plot rasio $\mathrm{Cl} / \mathrm{B}$, menunjukan semua manifestasi memiliki kesamaan asal fluida kecuali MB-2

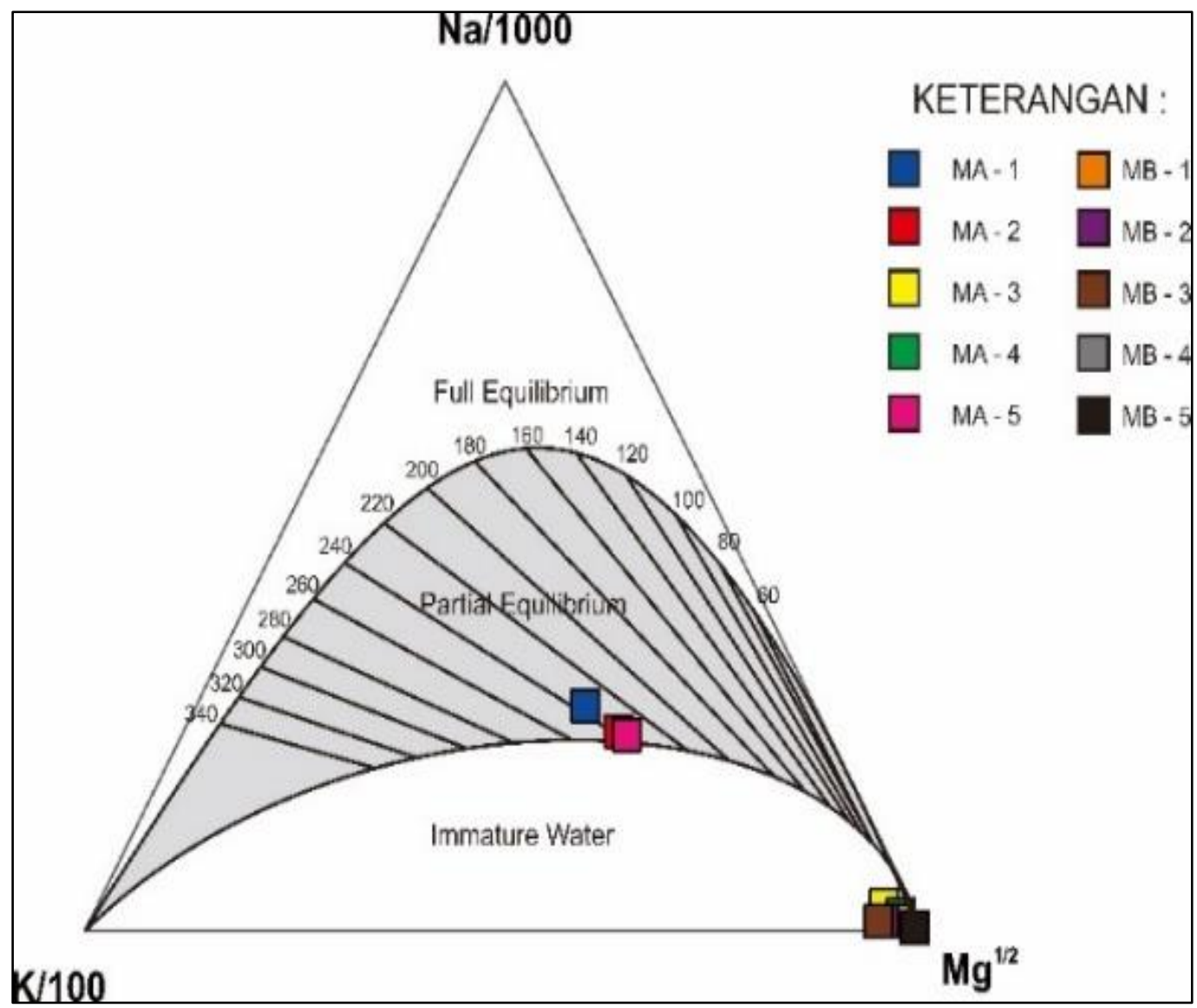

Gambar 7. Geoindikator Na-K-Mg 


\section{MAKALAH ILMIAH}

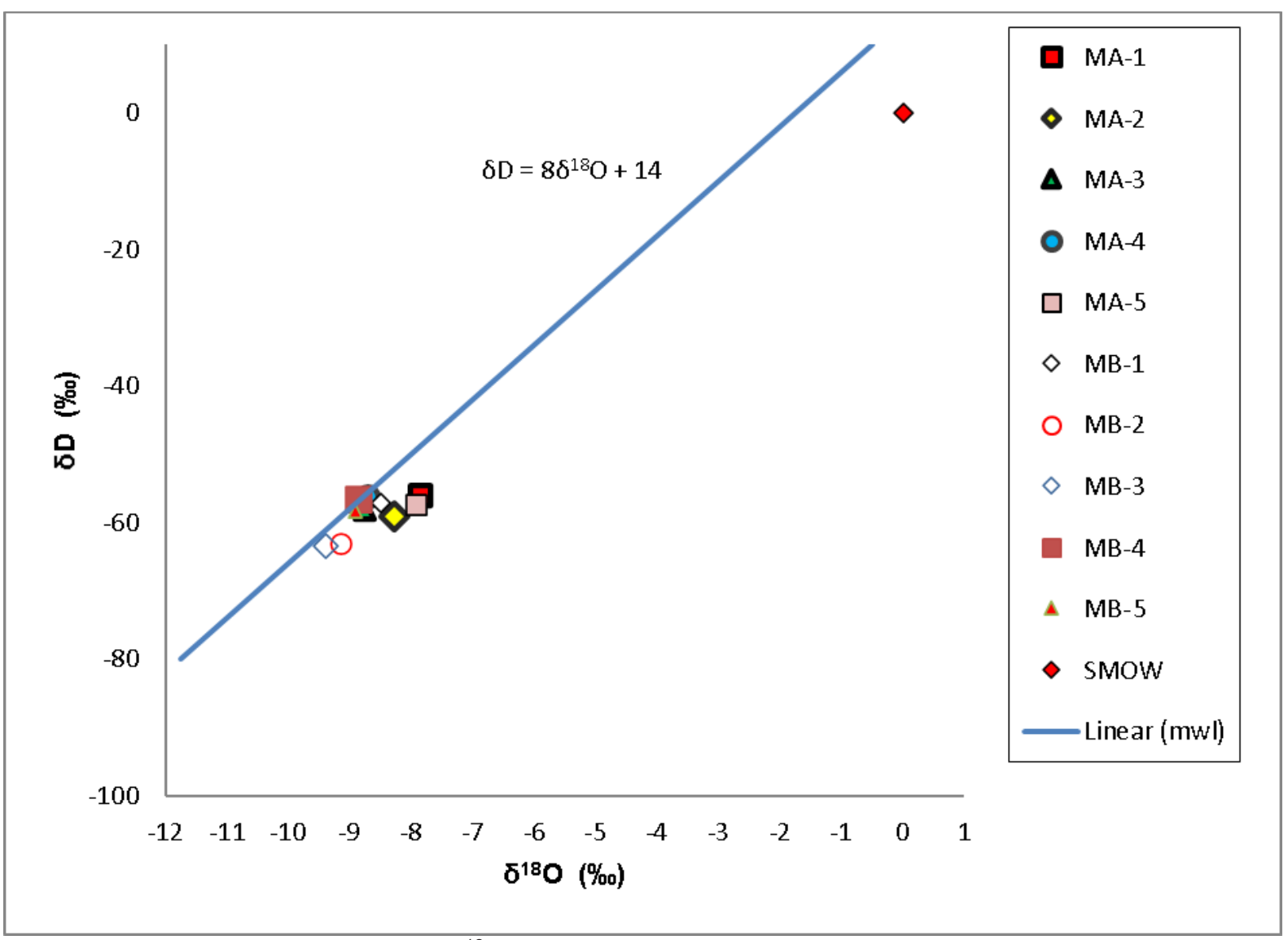

Gambar 8. Grafik Isotop ${ }^{18} \mathrm{O}$ dan D, air panas daerah panas bumi Sorik Marapi

\section{Model Aliran Fluida}

Pemodelan aliran fluida panas bumi daerah Sorik Marapi ini didasarkan pada data geologi, geoindikator fluida dan litologi sumur. Dari hasil analisis, manifestasi panas bumi kelompok MA (MA-1, MA-2, dan MA-5), bertemperatur paling tinggi $\left(101^{\circ} \mathrm{C}\right), \mathrm{pH}$ netral $(7)$, muncul pada bagian utara daerah penyelidikan, pada elevasi lebih rendah, daripada kelompok $\mathrm{MB}$, bertipe air klorida, dan dari perhitungan geotermometer Silika diperoleh $180^{\circ} \mathrm{C}$, serta NaK $235^{\circ} \mathrm{C}$. Merupakan indikasi yang paling representatif sebagai zona Outflow, dan kelompok MB sebagai Upflow, seperti yang digambarkan pada model aliran fluida (Gambar 9).

Mata air panas yang terdapat di daerah Sorik Marapi dapat dikelompokkan menjadi dua yaitu kelompok MB dan kelompok MA. Kelompok MB menempati elevasi lebih tinggi di sekitar keberadaan manifestasi fumarol. Kelompok mata air panas MA yang mempunyai elevasi lebih rendah yaitu di daerah sebelah utara dengan jarak sekitar $6 \mathrm{~km}$ dari kelompok mata air panas $\mathrm{MB}$ dan suhu air panas mencapai $100^{\circ} \mathrm{C}$ (boiling spring). Air panas kelompok MA mempunyai $\mathrm{pH}$ netral dan sebagian mempunyai kandungan kimia yang mencerminkan air yang berasal dari reservoir panas bumi (deep water) yang dapat disajikan dalam Tabel 2.

Dari hasil pengeplotan diagram segitiga $\mathrm{Cl}-\mathrm{SO}_{4}-\mathrm{HCO}_{3}$ (Gambar 4) terlihat beberapa mata air panas kelompok MA (MA-1,MA-2 dan MA-5) merupakan air klorida. Satu mata air panas dari kelompok MB yaitu MB-2 merupakan air klorida-sulfat dengan $\mathrm{pH}$ relatif lebih asam dari kelompok air panas MA. Selebihnya air panas yang lain lebih merupakan air yang didominasi air permukaan. Karakteristik air panas dari ke tiga sumber ini (MA-1,MA-2 dan MA-5) dianggap yang paling representatif untuk dipakai dalam pendugaan temperatur reservoir. Klorida adalah unsur yang pada 
suhu rendah di bawah $300^{\circ} \mathrm{C}$ akan berada pada fasa cair. Air dari reservoir bersuhu tinggi akan naik ke permukaan kemudian mengalir secara lateral mengikuti lereng dan muncul ke permukaan melalui zona lemah (sruktur geologi) di daerah elevasi lebih rendah menjauhi zona upflow. Hal ini umum terjadi pada daerah panas bumi dengan morfologi lereng terjal seperti daerah Sorik Marapi, sehingga air ini muncul di daerah outflow. Sedangkan air panas dari MB-2 mempunyai kandungan Mg yang cukup tinggi sehingga tidak represetatif untuk penghitungan geotermometer Na-K. Dari air panas MA-1, MA-2 dan MA-5 didapatkan perkiraan temperatur reservoir sebesar $220^{\circ} \mathrm{C}-235^{\circ} \mathrm{C}$ (Tabel 5). Perkiraan temperatur ini dianggap lebih mungkin karena tidak terpengaruh oleh adanya pengenceran air oleh air meteorik.

Dari pengeplotan ke diagram $\mathrm{Na} / \mathbf{1 0 0 0}$, $\mathrm{K} / 100$, dan $\sqrt{\mathrm{Mg}}$ (Gambar 6) juga menunjukan bahwa air panas MA-1, MA2 dan MA-5 berada pada zona partial equilibrium yang mencerminkan adanya air reservoir yang naik ke permukaan dan terdapat pencampuran dari air meteorik. Dari diagram ini juga mendukung penghitungan geotermometer $\mathrm{Na}-\mathrm{K}$ yang didapatkan perkiraan suhu reservoir berkisar $220^{\circ} \mathrm{C}-235^{\circ} \mathrm{C}$. Dari grafik isotop oksigen dan hidrogen $\left({ }^{18} \mathrm{O}\right.$ vs $\left.{ }^{2} \mathrm{H}\right)$ pada Gambar 7 terlihat adanya shifting lebih jelas pada kelompok air panas MA-1, MA2, dan MA-5 yang mengindikasikan telah terjadinya proses water-rock interaction dari air reservoir dan batuan yang dilaluinya sehinga adanya pengkayaan ${ }^{18} \mathrm{O}$ dalam air panas.

Dari pengamatan petrografis terhadap mineral ubahan yang terdapat dalam serbuk bor sumur X-06, X-08 dan XE01didapatkan kehadiran mineral indikator temperatur tinggi antara lain kehadiran mineral epidot. Kelimpahan mineral ubahan lain juga mengindikasikan adanya zona temperatur tinggi di kedalaman yang mengindikasikan adanya reservoir temperatur tinggi di Daerah Sorik Marapi.

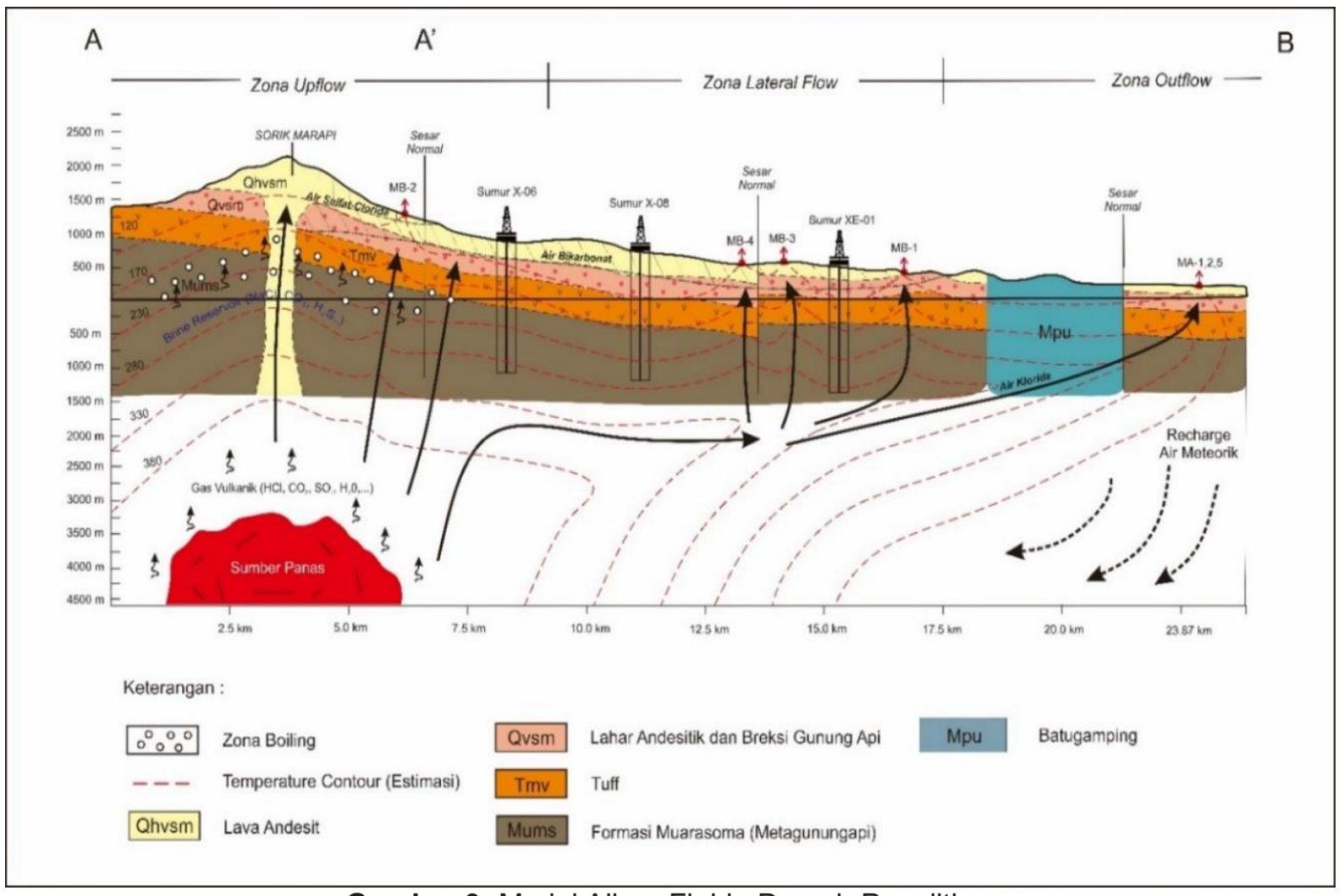

Gambar 9. Model Aliran Fluida Daerah Penelitian. 


\section{KESIMPULAN}

Berdasarkan geotermometer air panas dari kelompok mata air panas MA di dapatkan temperatur reservoir Sorik Marapi mencapai $220^{\circ} \mathrm{C}-235^{\circ} \mathrm{C}$ yang termasuk dalam kategori sistem panas bumi bertemperatur tinggi. Kelompok mata air panas MA merupakan air panas klorida dengan $\mathrm{pH}$ neutral muncul di zona outflow sistem panas bumi Sorik Marapi. Sedangkan air panas kelompok MB yang direpresentasikan oleh MB-2 dengan tipe sulfat-klorida dengan $\mathrm{PH}$ relatif lebih asam merupakan air panas yang muncul di zona upflow yang dikonfirmasi dengan keterdapatan jenis mineral ubahan indikator temperatur tinggi yang diperoleh dari serbuk bor sumur X-06, X-08, dan XE01. Fluida panas dalam sistem panas bumi Sorik Marapi dari reservoir temperatur tinggi di bawah mata air panas MB-2 mengalir ke atas dan secara lateral mengalir ke arah utara berinteraksi dengan batuan yang dilalui dan muncul sebagai kelompok manifestasi MA di zona outflow.

\section{UCAPAN TERIMAKASIH}

Penulis mengucapkan terimakasih kepada PT. Sorik Marapi yang telah memberikan kesempatan untuk melakukan penelitian di lapangan Sorik Marapi.

\section{DAFTAR PUSTAKA}

Barnes, L. H, 1997, Geochemistry of Hydrothermal Ore Deposits, reprinted $3^{\text {rd }}$ Edition, USA

Bateman, A.M, and Jensen, M.L., 1981. Economic Mineral Deposits. John Wiley and Sons, Australia.

Browne P.R.L dan Brown.K., 1996, Geothermal Technology: Earth Science Notes, Material for Teaching the Teachers Course III, Geothermal Institute, Institute Univ. of Auckland.

Corbett, G.J., dan Leach, T.M., 1996, Southwest Pacific Rim Gold-Copper System: Structure, Alteration, and Mineralization, Manual Kursus Singkat Eksplorasi di Baguio, Philippines.
Darman, H. dan Sidi, F.H. 2000. An Outline of The Geology of Indonesia. Ikatan Ahli Geologi Indonesia.

D.T. Aldiss. 1983. Peta Geologi Regional Lembar Lubuk Sikaping, Sumatra Utara. Departemen Pertambangan dan Energi, Direktorat Jendral Geologi dan Sumberdaya Mineral, Pusat Penelitian dan Pengembangan Geologi, Bandung.

Dickson, M.H. and Fanelli, M. .2004. What Is Geothermal Energy? International Geothermal Association, Bochum.

Giggenbach, W.F., 1988. Geothermal solute equilibria. Derivation of Na-K$\mathrm{Mg}-\mathrm{Ca}$ geoindicators. Geochim Cosmochim. Acta, 52: pp. 27492765.

Giggenbach, W.F., 1989: The chemical and isotopic position of Ohaaki field within the Taupo Volcanic Zone. Proc. Eleventh N.Z. Geothermal Workshop, Aukland: pp. 81-88.

Giggenbach, W. F., 1991, Chemical Techniques in Geothermal Exploration, Application of Geochemistry In Geothermal Reservoir Development.

Guilbert, J. M., Park, C. F., 1986, The Geology of Ore Deposits, WH.Freeman and Company, New York.

Henley RW, Truesdell AH, Barton Jr. PB, Whitney JA. 1984. Fluid-Mineral Equilibria in Hydrothermal Systems.

Hochstein, M.P. dan Browne, P.R.L. 2000. Surface Manifestation of Geothermal Systems with Volcanic Heat Sources, In Encyclopedia of Volcanoes, $\mathrm{H}$. Sigurdsson, B.F.. Houghton, S.R., McNutt, H., Rymer dan J. Stix (eds.), Academic Press.

Juliarka R. B.\& Iqbal M, 2020. Model Gaya Berat 2D untuk mengungkap Struktur Geologi Bawah Permukaan Pada Daerah Panas Bumi Natar. Buletin Sumber Daya Geologi, Vol. 15 No.1 pp 39-49.

Morrison, K. 1997. Important Hydrothermal Minerals and their Significance. Geothermal and mineral Services Division Kingston Morrison Limited, Seventh Edition, New Zealand. 


\section{MAKALAH ILMIAH}

Oppenheimer, C. (1995). K. N. Nicholson, 1993. Geothermal Fluids. Chemistry and Exploration Techniques. xv 263 pp. Berlin, Geological Magazine, 132(1), 125-126.

Powell, T. 2000. A Review of Exploration Gas Geothermometry. Proceedings, TwentyFifth Workshop on Geothermal Engineering, Stanford University, Stanford, California.

Powell, T. and Cumming, W. 2010. Spreadsheets For Geothermal Water and Gas Geochemistry. Proceedings, Thirty-Fifth Workshop on Geothermal Reservoir Engineering, Stanford University, Stanford, California.

Rahadinata, T. Takodama I, Zarkasyi A, 2019. Penerapan Koreksi Topografi Pada Data Magnetotelurik dan Analisis Data Gaya Berat Dalam Interpretasi Daerah Panas Bumi
Pantar, Kabupaten Alor, Provinsi Nusa Tenggara Timur. Buletin Sumber Daya Geologi Vol. 14 No.3, pp 156-168.

Reyes, G.A. 2000. Petrology and Mineral Alteration in Hydrothermal System: From Diagenesis to Volcanic Catastrophes. Geothermal Training Programme, United Nations University, Reykjavik, Iceland.

Simmon, S.F. 1995. Geothermal Technology: Geochemistry. Pertamina Course, Cirebon.

Sumintadireja, P., 2005, Vulkanologi dan Geothermal, Penerbit ITB, 153hal.

Thompson, A.J.B, Thompson J.F.H 1996. Atlas of Alteration: $A$ field and Petrographic Guide to Hydrothermal Alteration Minerals. Geological Association of Canada Mineral Deposit Division, Canada.

$\begin{array}{ll}\text { Diterima } & : \text { 15 September } 2020 \\ \text { Direvisi } & : 21 \text { September } 2020 \\ \text { Disetujui } & : 30 \text { November } 2020\end{array}$

